研

究

\title{
純マグネシウム粉末の圧縮性と焼結性に及ぼす温間成形の影響
}

\author{
岩岡拓的，中村満的 2 \\ 的東京都立産業技術研究センター, テ 115-8586 東京都北区西が丘 3-13-10. \\ 的岩手大学工学部, $=020-8551$ 盛岡市上田 4-3-5.
}

\section{Effects of Warm Compaction on Compressibility and Sinterability of Pure Magnesium Powder}

\author{
Taku Iwaoka ${ }^{\text {मे } 1}$ and Mitsuru Nakamura ${ }^{\text {负 } 2}$ \\ ${ }^{\text {is }}$ Tokyo Metropolitan Industrial Technology Research Institute, 3-13-10 Nishigaoka Kita-ku, Tokyo 115-8586, Japan. \\ ${ }^{2}$ Faculty of Engineering, Iwate University, 4-3-5 Ueda, Morioka 020-8551, Japan.
}

Received October 20, 2010

SYNOPSIS

Warm compaction is known as an efficient way to increase green density, which contributes to increase strength after sintering. In this study, the application of a warm compaction method to the pure magnesium powder was investigated. The compressibility and compaction behavior of pure magnesium powder compacted at various temperatures and pressures were measured. The porosity and ejection stress of the pure magnesium green compacts processed at $373 \mathrm{~K}$ under a pressure of $489 \mathrm{MPa}$ were about $0.5 \%$ and $1.4 \mathrm{MPa}$, respectively. It was found that sintered transverse rupture strength of the warm compacted specimens is higher than that of the cold compacted specimens. The difference in strength between cold and warm compacted specimens increased with increasing sintering temperature. The maximum difference was about $40 \mathrm{MPa}$. The increase of the sintered strength is considered to be due to the increase in contacting area among the powder particles promoted by the warm compaction. In conclusion, the experimental results showed that the warm compaction method is an effective method to compact a pure magnesium powder into near full density and therefore to increase the sintered strength.

KEY WORDS

warm compaction method, pure magnesium powder, compressibility, compaction behavior, sinterability

\section{1 緒言}

$\mathrm{Mg}$ 等の活性金属は, その粉末粒子表面に形成される酸化皮 膜によって, 焼結の進行が阻害されることが知られている ${ }^{1-4)}$. 従来，それらの活性な金属粉末の成形および焼結には，酸化 皮膜の破壊および母相中へ酸化物の分散"5を称らったホッ卜 プレスおよび熱間押出し等の強加工が用いられてきた。これ らの工法は，アトマイズ法执よびMA法等の粉末製造法を併 用することで，優れた機械的性質，耐熱性および耐摩耗性等 を焼結材料に付与することが可能である ${ }^{6-11)}$. その反面，常 圧焼結法に比べて複雑形状を有する焼結材料が得られにくく， 製造コストがかかるため, 粉末冶金法本来の特徵を活かしき れなり側面を持つ ${ }^{8.12)}$ 。また，COP15における温室効果ガス 削減の国際公約によって，より一層，環境低負荷かつ高品質 な製品を効率上く製造する方法が求められており, $\mathrm{Mg}, \mathrm{Al}$ 㐨 よびTi合金等の軽金属材料による軽量化，高機能化および低 コスト化に拍車がかかっている．しかし，通常の粉末治金法
における純 $\mathrm{Mg}$ 粉末の圧縮成形は，Fig.1 に示す通り，純 $\mathrm{Mg}$ 圧粉体の低気孔率を得るためには $1000 \mathrm{MPa}$ 程度の高い成形圧 力を要し, 作製された圧粉体内部には, 成形圧力の高低に関 わらず, 圧縮軸に垂直な方向に圧粉体を大きく横切る程のラ ミネーションクラックがしばしば生じることから，純 $\mathrm{Mg}$ 粉 末の圧縮性は著しく乏しい，その結果，得られる焼結体の強 度が低いことが問題となっている。

そこで本研究は, $\mathrm{Fe}$ 系粉末ですでに適用されている温間成 形法 ${ }^{13,14)}$ に注目した. 温間成形法は, 上述の強加工に比べて, 設備や工程数の点で生産効率がよく, $373 \mathrm{~K}$ 程度の加熱によ り粉末の圧縮性を高めることから, 比較的容易に焼結体の密 度および強度特性を向上させることが可能な工法である.し たがって，温間成形により，マグネシウムの塑性変形能を高 めることで, 純 $\mathrm{Mg}$ 粉末の圧縮性が改善される可能性がある. また, 非鉄系においては, Al 系粉末に温間成形法の適用を検 討した報告がいくつかあるが，Mg系粉末に関する報告はほ 


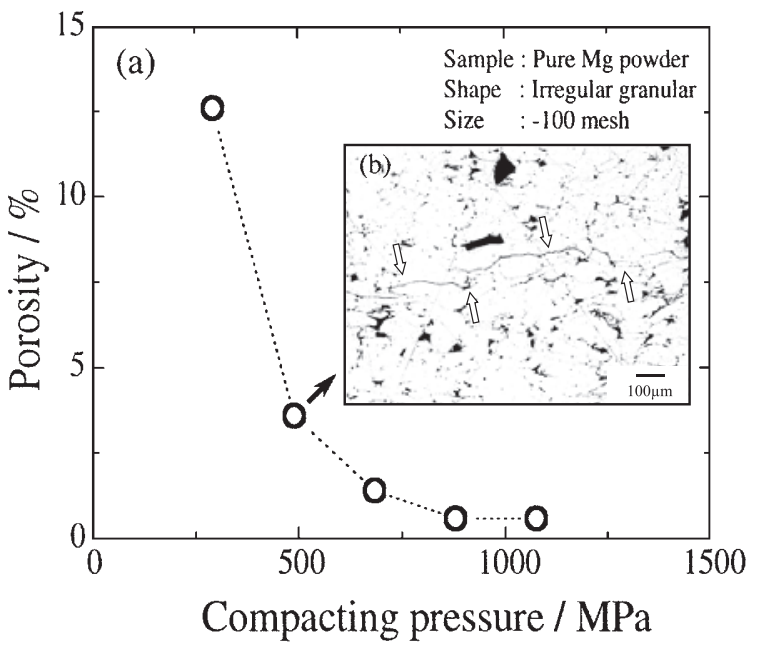

Fig.1 Compressibility of pure magnesium powder during cold compaction: (a) Relation between porosity and compacting pressure, (b) Lamination cracks indicated by arrows were observed in pure magnesium green compact that was pressed at $489 \mathrm{MPa}$.

とんどない，ゆえに，温間成形法を用いて純 $\mathrm{Mg}$ 粉末を圧縮 成形した後, 常圧焼結を行うことで, 純 $\mathrm{Mg}$ 粉末のバルク化 を試み，得られた純 $\mathrm{Mg}$ 焼結体の焼結特性について調べ，温 間成形法の有効性について検討を行った。

\section{2 実験方法}

Fig. 2 は, 温間成形法で用いる成形金型の模式図を示す. 粉 末および成形金型を加熱すために成形金型側面にバンドヒー 夕を装着してある。供試粉末である純 Mg 粉末の SEM 像を Fig.3に示す.純Mg粉末は, 中央工産侏)製の粉砕粉 $(-100$ mesh, 99.8\%)を用いた.この粉末を黒鈆一有機バインダー系潤滑剤 を塗布した成形金型に充填して，293〜1075 MPaの成形圧力 範围で圧縮成形することで，純 $\mathrm{Mg}$ 圧粉体を作製した．成形 方式は，压粉体の密度分布がより均一となるフローティング ダイ方式を採用した。成形温度は，301, 373 および $473 \mathrm{~K}$ と し,粉末を直接測温することで制御した. 圧粉体の気孔率, 抜 出力および半径方向の寸法変化を調べることで, 純 $\mathrm{Mg}$ 粉末の 圧縮性を評価した、気孔率は，圧縮軸方向に平行な断面中央

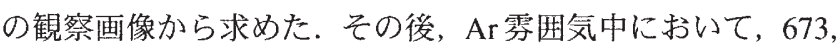
773 および $873 \mathrm{~K}$ の各温度で $0.36 \sim 18 \mathrm{ks}$ の保持にて常圧焼結を 行った，昇温速度および领却速度は，それぞれおよそ $0.12 \mathrm{~K} / \mathrm{s}$ および $0.07 \mathrm{~K} / \mathrm{s}$ であった．得られた焼結体の焼結特性を評価 するために，万能試験機 (AG-10TD，怢島津製作所)を用いて 圧縮試験および抗折試験を行った。試験片寸法は，それぞれ $\phi 11.3 \times 14.7 \mathrm{~mm}^{3}$ および $10 \times 36 \times 6 \mathrm{~mm}^{3}$ とした。 クロスヘッ ド速度は， $1 \mathrm{~mm} / \mathrm{min}$ とし，試験片が破壊されるまで試験を 行った. 焼結体の抗折試験後の破面および粉末粒子界面近傍 の観察は，SEM (ERA-8900FE，侏エリオニクス)およびEDS (Genesis，アメテック侏) を用いて行った.

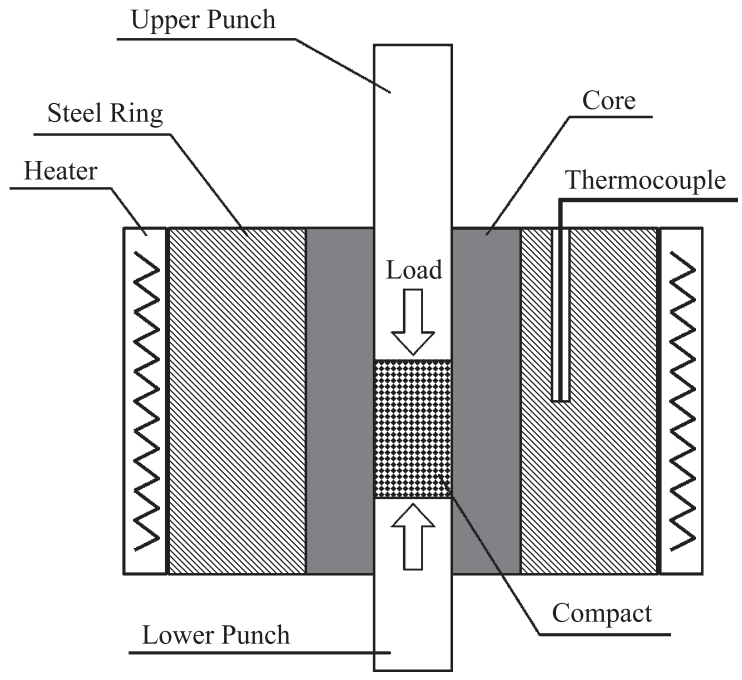

Fig.2 Schematic illustration of the die assembly used for the warm compaction method.

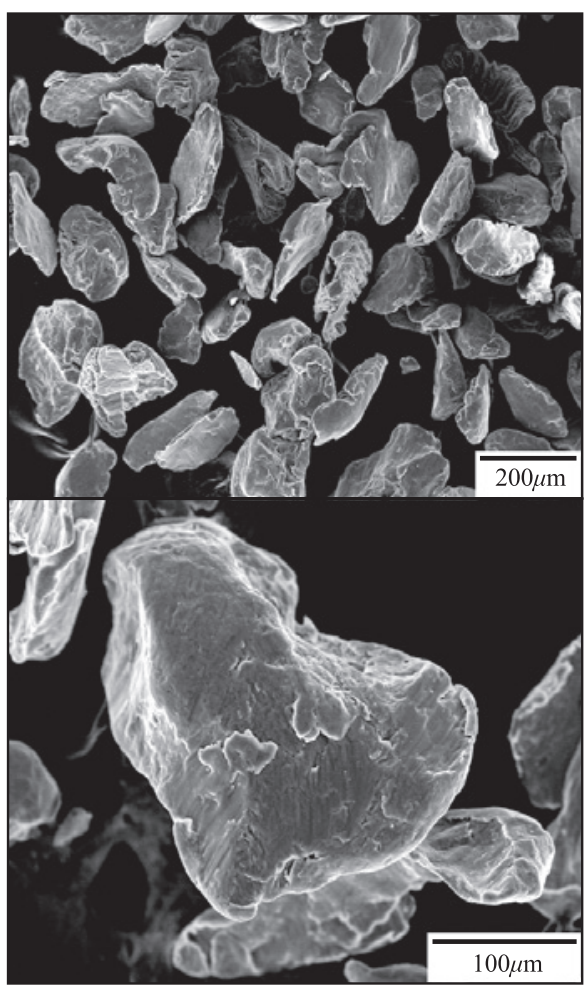

Fig.3 SEM images showing the morphology of the pure magnesium powders.

\section{3 実験結果および考察}

3.1 圧縮成形挙動

Fig.4 は, 純 Mg 圧粉体の気孔率と成形温度の関係を示す。 成形圧力が $489 \mathrm{MPa}$ の場合, 成形温度が $373 \mathrm{~K}$ にて気孔率は 著しく減少し，成形压力が $1075 \mathrm{MP}$ の場合の冷間成形時の気 孔率とほぼ同等の值を示した. Fig.5は, 各成形条件における 純 $\mathrm{Mg}$ 圧粉体の圧縮軸方向に平行な断面中央の気孔分布を示 す、それぞれの気孔率も図中に示してある. 冷間成形を行つ 


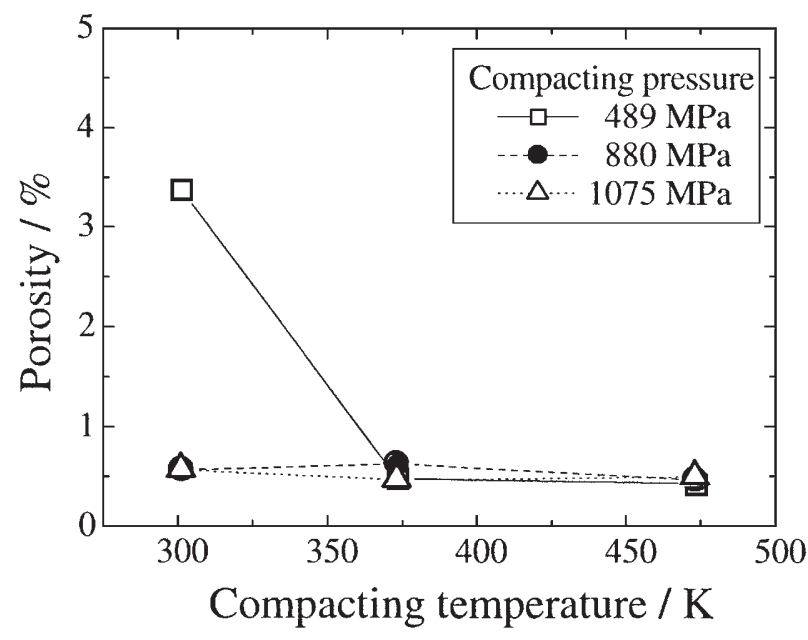

Fig.4 Relation between porosity of the pure magnesium green compacts and compacting temperature.

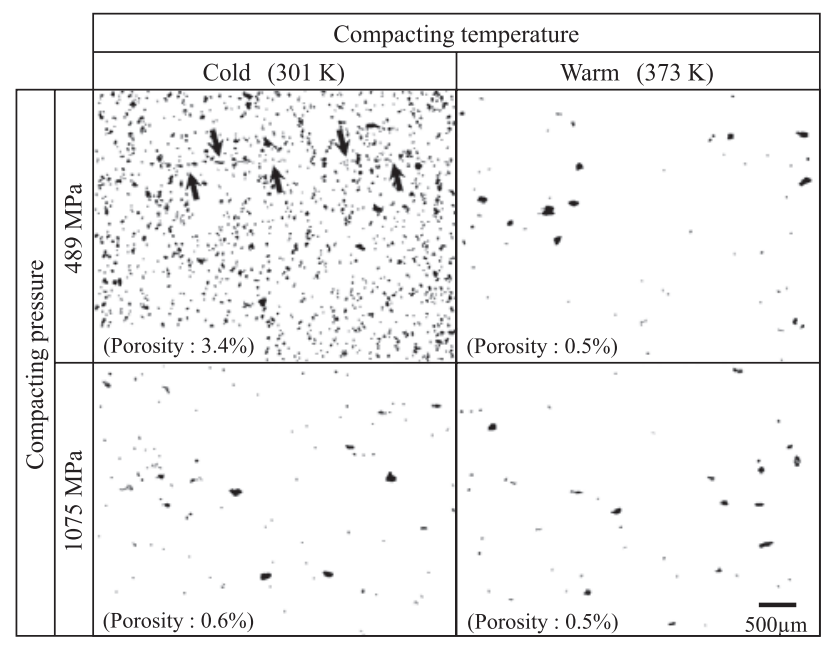

Fig.5 The pore distribution of a longitudinal section in the pure magnesium green compacts that was compacted at $489 \mathrm{MPa}$.

た場合, 成形圧力の増加によって $20 \sim 30 \mu \mathrm{m}$ の大きさの気孔 は減少し, $100 \mu \mathrm{m}$ 程度の比較的粗大な気孔がわずかに残存し ていた。一方, 温間成形を行った場合, 矢印で示すラミネ一 ションクラックの完全な消失と, 成形圧力が低いにも関わら ず気孔の著しい減少が観察された。このことから，圧縮性の 乏しい純 $\mathrm{Mg}$ 粉末に温間成形を用いることで, $\mathrm{Fe}$ 系等の金属 粉末の常識的な成形圧力に近い $500 \mathrm{MPa}$ 程度の成形圧力でも 圧縮成形が可能であり, その結果, 高密度の圧粉体が得られ ることがわかった。

Fig.6は, 純 $\mathrm{Mg}$ 圧粉体の抜出力とスプリングバックの関係 を示す，成形温度の上昇に伴って抜出力およびスプリング バックは減少した。 成形圧力が 1075 MPの場合, その高圧力 によって, 圧粉体側面と成形金型内壁との潤滑機能の低下が 起こり，拔出力はさらに大きくなったと考えられる. 成形圧 力が $489 \mathrm{MPa}$ の場合, 拔出力およびスプリングバックの関係

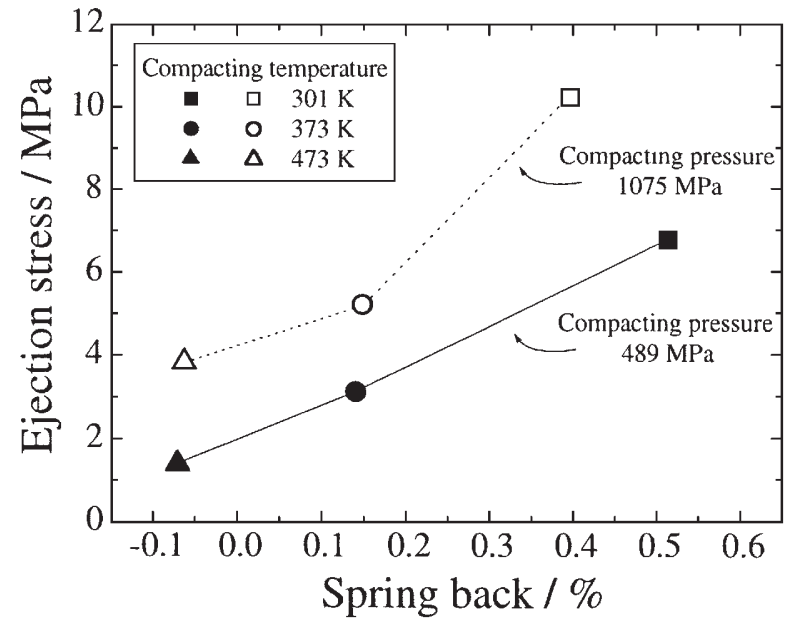

Fig.6 Relation between ejection stress and spring back of the pure magnesium green compacts that were compacted at 489 MPa.

はほぼ直線的であった. 抜出力は压粉体側面と成形金型内壁 との間に生じる摩擦力によって決定される圧粉体の拔き抵抗 を示す. 报き抵抗の增加要因としてまず金型への焼付きが懸 念されたため, 圧粉体側面および成形金型内壁の潤滑状態に ついて調べた. その結果, 成形温度に関わらず, 报出し後の 圧粉体の側面に, 圧縮軸方向に沿ってメタルフローが観察さ れた. また, 成形金型内壁には, 塗布された潤滑剤の一部が 粉末粒子間の間隙によってかき取られた様子が見られたが, 成形温度の上昇による潤滑剤のかき取られた量や分布への影 響はほとんど見られなかった．以上のことから，金型への焼 付きに伴う抜き抵抗の增加はなかったと考えられる。した がって, この抜出力は, 压縮成形過程において黒鉛による潤 滑機能にはほとんど影響されず，主に，圧粉体に蓄積された 弾性エネルギーによって, 圧粉体がその半径方向に膨張しょ うとして生じる成形金型内壁への負荷応力によってもたらさ れたと考えられる.すなわち, 温間成形による拔出力の減少 は, 圧粉体を成す個々の純 $\mathrm{Mg}$ 粉末粒子に弾性変形ではなく 塑性変形が主として起こったことを明示する.

室温から $373 \mathrm{~K}$ における純 $\mathrm{Mg}$ の降伏強度の温度依存性は 純 Feに比べて大きく ${ }^{15.16)}$, 水嶋ら ${ }^{16)}$ によると, 純 $\mathrm{Mg}$ 板材の $0.2 \%$ 耐力は $39 \%$ 低下することが報告されている. 本実験の 純 $\mathrm{Mg}$ 粉末においても, 通常の金属粉末成形で得ら机る圧粉 密度と比較して同等あるいはそれ以上の高密度圧粉体が得ら れることから, その圧縮成形過程は, 粉末の再配列などの挙 動は最早考えられず, 粉末粒子の塑性変形が加工硬化と拮抗 して, どこまで気孔を塞ぐように変形できるかどうかに依存 すると考えられる，また，スプリングバックの低下も，成形 温度の上昇によって, 圧粉体のヤング率が低下し, 降伏強度 が低下したため起こったと考えられる，したがって，温間成 形によるこれらの挙動は, 主として純 $\mathrm{Mg}$ 粉末の降伏強度の 温度依存性が影響していると考えられる。 


\section{2 焼結性}

Fig.7 は, 純 Mg 焼結体の圧縮強さと気孔率の関係を示す。 焼結温度が $673 \mathrm{~K}$ において, 成形温度の上昇に伴い, 焼結体 の気孔率が減少し, 点線に示す通り焼結体の圧縮強さは緩や かに増加した。一方, 焼結温度が $873 \mathrm{~K}$ に抢いては, 成形温 度が $301 \mathrm{~K}$ では圧縮強さと気孔率の関係は点線上にあり，圧 縮強さは気孔率の影響下にあった。 しかし, 成形温度が 373 および $473 \mathrm{~K}$ では，その傾向から外れて，実線に示す通り，気 孔率のわずかな減少により圧縮強さは大きな増加傾向を示し た.この圧縮強さの増加は, 気孔による焼結体内部の構造状 態よりむしろ粉末粒子同士の結合状態に起因すると推測され る. そこで，焼結体の抗折力を調べ，その粉末粒子間の結合 力について評価した. Fig.8は, 各試料の抗折力を示す. 抗折 力は焼結を行うことで増加し, 焼結温度の増加によってさら に増加した．また，その増加量は冷間成形よりも温間成形の 方が大きいことがわかった．したがって，温間成形によって 純 $\mathrm{Mg}$ 粉末の焼結が進行し，粉末粒子間の結合力が増加した ため，抗折力が増加したと考えられる．

金属やセラミックスでの焼結現象は，体積拡散，表面拡散 および粒界拡散によるネックへの物質移動が支配的であり， それぞれの機構に対応した焼結速度式17.18)が考えられている. Kuczynskiのネック成長の式 ${ }^{19}$, Fickの第 1 法則にもとづいた 拡散の式 ${ }^{20}$ ならびに若干の仮定等を用いて, 粉末粒度や焼結 時間等を含む焼結体の収縮および強度に関する一般式が, 渡 辺 ${ }^{18)}$ により導出されている.この一般式から，例えば，焼結 体の抗折力 $\sigma$ は焼結時間 $t$ の関数として, 任意の定数 $a$ および $b$ を用いて簡易的に次式で示される.

$$
\sigma=a t^{b}
$$

したがって，理論上，抗折力と焼結時間の両対数プロットは 直線関係となる. 定数 $a$ は成形条件および焼結条件により決 定され，定数 $b$ は拡散機構により決定される. そこで, 純 $\mathrm{Mg}$ 粉末の焼結性に及ぼす温間成形の影響についてさらに検討す

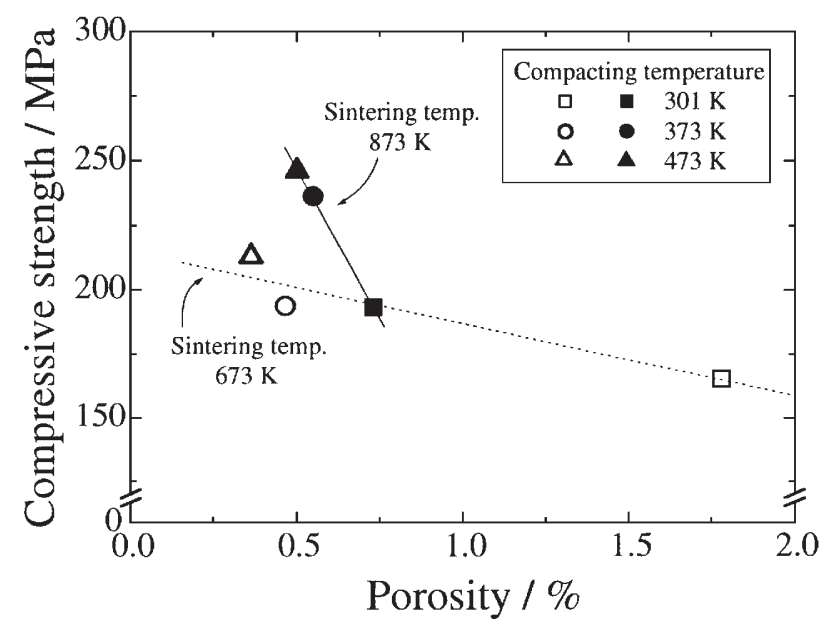

Fig.7 Relation between compressive strength and porosity of the pure magnesium sintered compacts.
るため, 純 Mg焼結体の抗折力と焼結時間の関係を調べた. そ の結果をFig.9に示す. 焼結時間の增加に伴って, 成形温度に 関わらず抗折力は增加傾向を示した. 冷間成形および温間成 形の両者おける直線の傾きに差はほとんど認められなかった。 本実験では, 純 $\mathrm{Mg}$ 粉末の粒度分布および粉末形態等の複雑 さにより, 焼結速度式から焼結機構を詳細に検討するには困 難を要するが, その両者には, 酸化皮膜を介した同様の機構 が衝いていたと考えられる，一方，冷間成形の場合に比べて 温間成形の場合の方が, 全ての焼結時間において抗折力は大 きい值を示した.この差は, 焼結速度式の関係から定数 $a$ の 差に相当し，粉末特性あるいはネック形成にも依存する。し たがって, 温間成形によって, 粉末粒子同士が互いに塑性変 形および接触を起こすことで接触面積が増加し, 粉末粒子同 士の結合部分が拡大したため抗折力が増加したと推測される.

Fig.10は, 焼結時間を変化させたときの焼結体の抗折試験 後の破面観察結果を示す．冷間成形で焼結時間が短い場合,

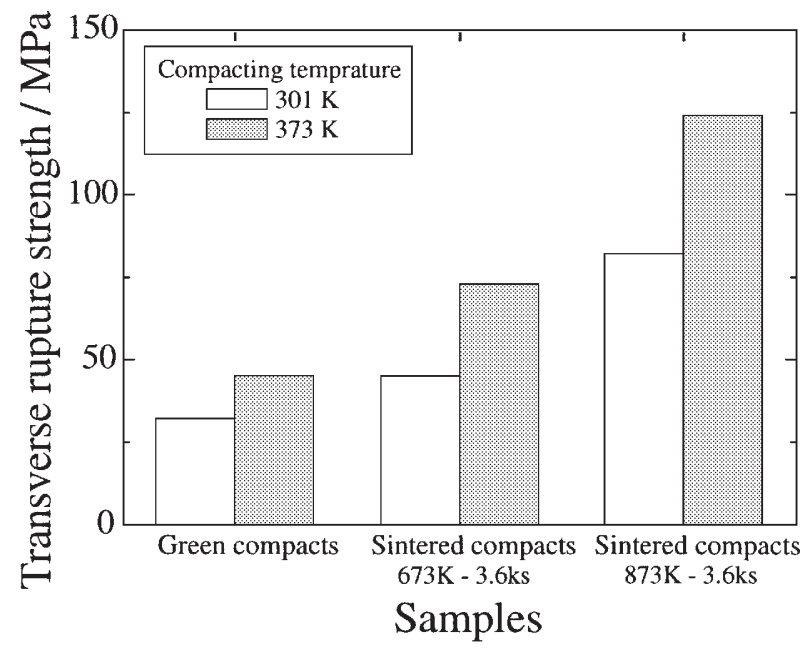

Fig.8 Transverse rupture strength of the pure magnesium green compacts and sintered compacts.

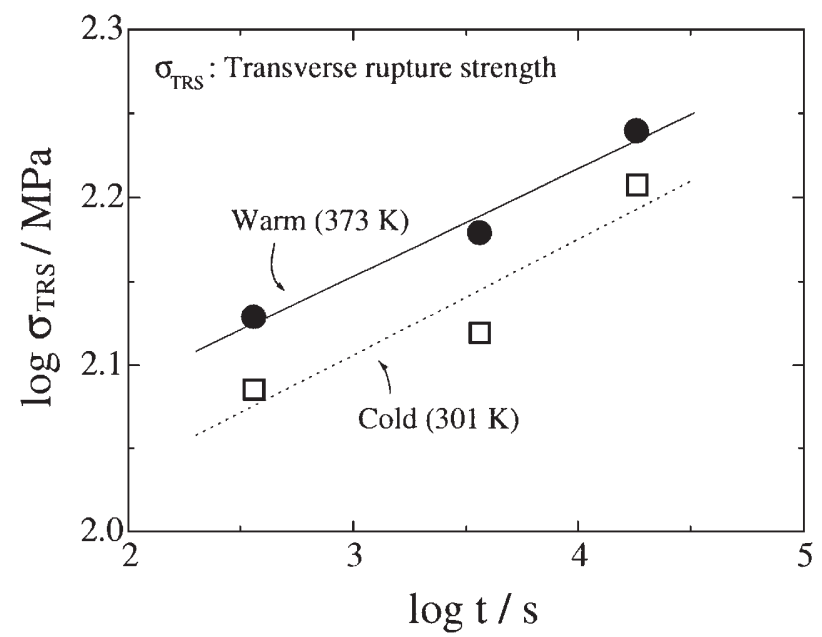

Fig.9 Double logarithmic plot of the transverse rupture strength versus the sintering time (Compacting pressure: $489 \mathrm{MPa}$ ). 


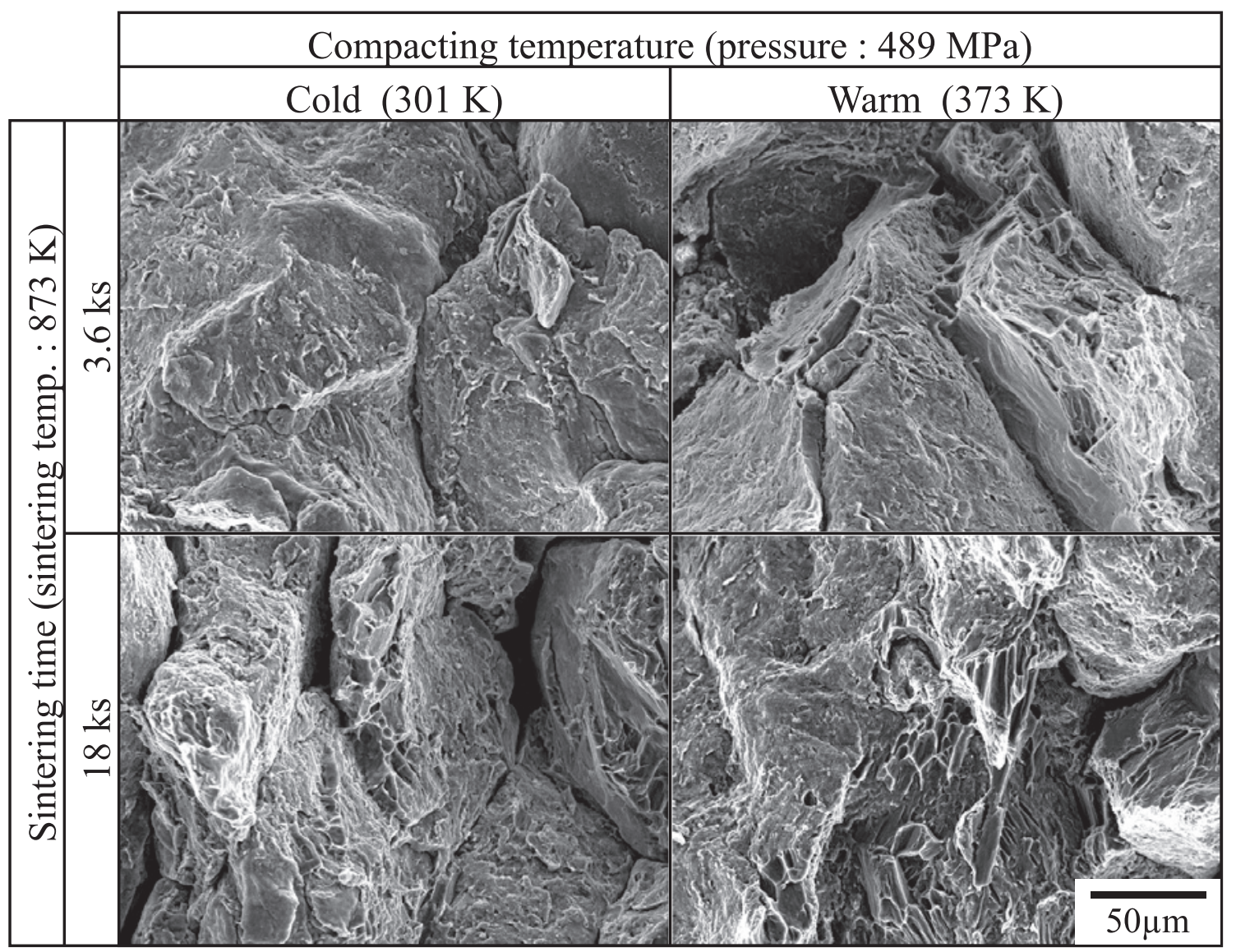

Fig.10 SEM images of the fractured surface of the transverse ruptured specimens.

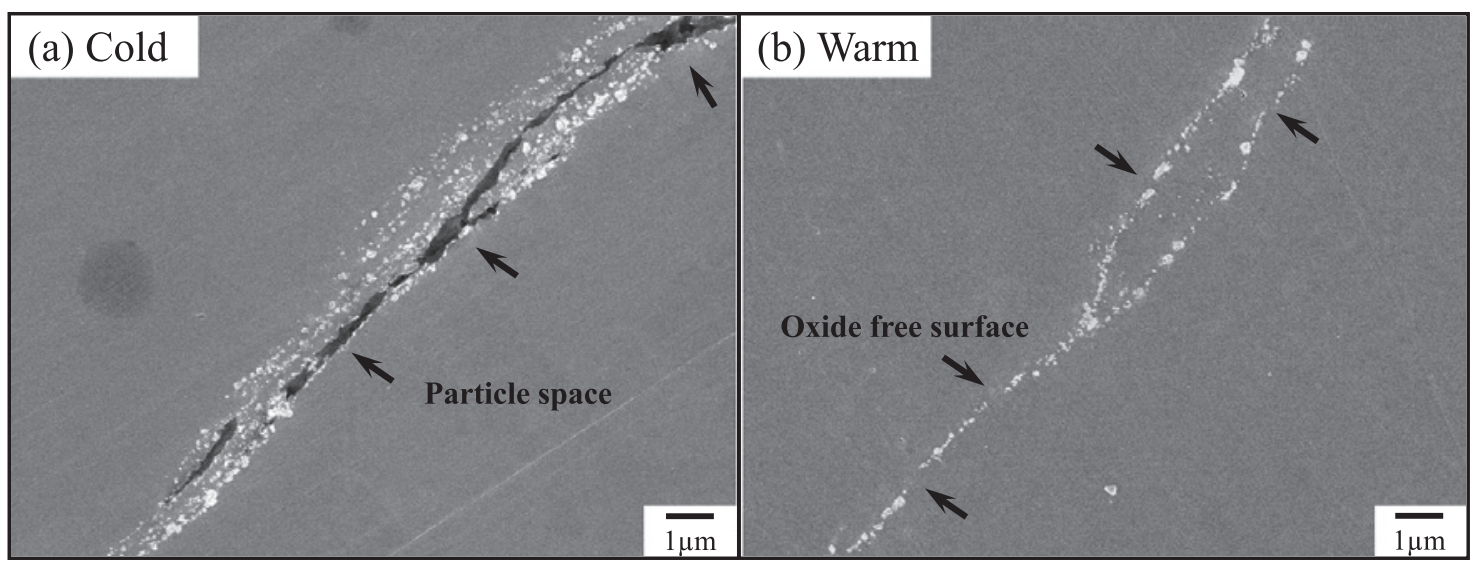

Fig.11 SEM image showing the neighborhood of the interface between powder particles in magnesium sintered compacts: (a) cold compacted specimens and (b) warm compacted specimens.

その破面は粉末粒子表面がほとんど観察され, 粉末粒子の輪 郭もわかりやすいため, 破壊のほとんどは粉末粒子間で生じ たと考えられる. 一方, 温間成形の場合は, 粉末粒子同士の 結合が破壊された様子が部分的に観察された.さらに, 焼結 時間を長くするとその破壊された領域がかなり拡大されてい ることから, 粉末粒子同士の接触面積も増加したと考えられ る. Fig.11は, 温間成形により圧粉した後, $873 \mathrm{~K}$ の焼結温度
で $18 \mathrm{ks}$ 保持した焼結体の粉末粒子の界面近傍のSEM 像を示 す. Fig.11 (a) は冷間成形後焼結した試料である. 粉未粒子界 面に沿って白色物が不連続に観察された. EDS 分析の結果, 白色物は酸素濃度が高いことから酸化皮膜であると考えられ る. 粉末粒子間には間隙が多く観察されたことから, 粉末粒 子同士の接触は良好とは言えない, 一方, Fig.11 (b) は温間成 形後焼結した試料である. Fig.11 (a) と同様に不連続な酸化物 
が観察されたが，粉末粒子間の間隙はほとんど観察されな かった. したがって, Fig.11 (a) と比べて粉末粒子同士の接触 も良好であることから，新生面も生じ易く，その結果，抗折 力が増加したと考えられる。

純 $\mathrm{Mg}$ 粉末の圧縮成形挙動において, 成形温度の上昇に伴 う圧縮性向上の主要因は, 降伏強度の温度依存性であり, 粉 末粒子の十分な塑性変形が温間成形によってもたらされたと 考えられるが，焼結性においても，その温間成形の効果につ いてより明確にするために，880 MPaの高圧力成形時の冷間 および温間における焼結性の比較を行った。その結果を Fig.12に示す. Fig.9 と同様に, 図中の実線抢よび点線は，そ れぞれ温間成形および冷間成形した場合の焼結体の抗折力と 焼結時間の関係を示す. Fig.9 と Fig.12 を比較すると, Fig.12 の成形圧力が $880 \mathrm{MPa}$ の場合，冷間および温間の抗折力の差 は見られず, 冷間成形の場合の直線がそのまま温間成形の場 合の直線までシフトしている様子がうかがえる. 抗折試験後 の破面形態も大きな変化は見られなかったことから, 高圧力 成形の場合, 粉末粒子同士の結合領域は成形温度に関わらず ほぼ同等であったと考えられる，換言すると，冷間成形で あっても高圧力成形を行うことで, 粉末粒子の塑性変形が促 され，粉末粒子同士の接触を良好にしたため，温間成形と同 等の焼結性が得られたと考えられる。 すなわち, 純 Mg 粉末 の降伏強度の温度依存性により, 成形温度の上昇に伴って粉 末粒子の塑性変形を容易にもたらすことが温間成形の効果と 結論付汀られる.

これらのことから，温間成形法を用いることで，純 $\mathrm{Mg}$ 粉 末の焼結は促進されたことが確認された。純 $\mathrm{Mg}$ 粉末の圧縮 成形における粉末粒子同士の塑性変形および良好な接触に よってその焼結性が向上したことは至極当然でありながら最 も重要なことである.それを比較的容易に行うことが可能な 温間成形法は純 Mg 粉未を焼結する上で有効である.

\section{4 ま と め}

純 $\mathrm{Mg}$ 粉末の圧縮成形に温間成形法を適用することで純 $\mathrm{Mg}$ 圧粉体を作製し，その圧縮成形挙動および焼結性について評 価した結果を以下に要約する。

(1) 成形温度 $373 \mathrm{~K}$ において, 純 $\mathrm{Mg}$ 粉末の気孔率は著しく減 少し, 高圧力成形でしか得られない低気孔率を, その約半 分の成形圧力で達成することが可能であった。

(2) 成形温度の上昇に伴って, 純 $\mathrm{Mg}$ 圧粉体に生じるラミネー ションクラックおよびスプリングバックが抑制された. その結果, 圧粉体の抜出力は減少した.これらのことから 純 $\mathrm{Mg}$ 粉末の圧縮性は向上した.

（3） $873 \mathrm{~K}$ で焼結した焼結体の圧縮強さは，673K で焼結した ものに比べて気孔率に影響されずに，成形温度の上昇と 伴に増加した。 その増加量はおよそ $50 \mathrm{MPa}$ であった。

(4) 純 Mg 焼結体の抗折力は, $489 \mathrm{MPa}$ 成形の場合, 冷間およ び温間の差が見られ, $880 \mathrm{MPa}$ 成形の場合はその差が見ら れなかった.したがって, 温間成形の効果は, 主として純

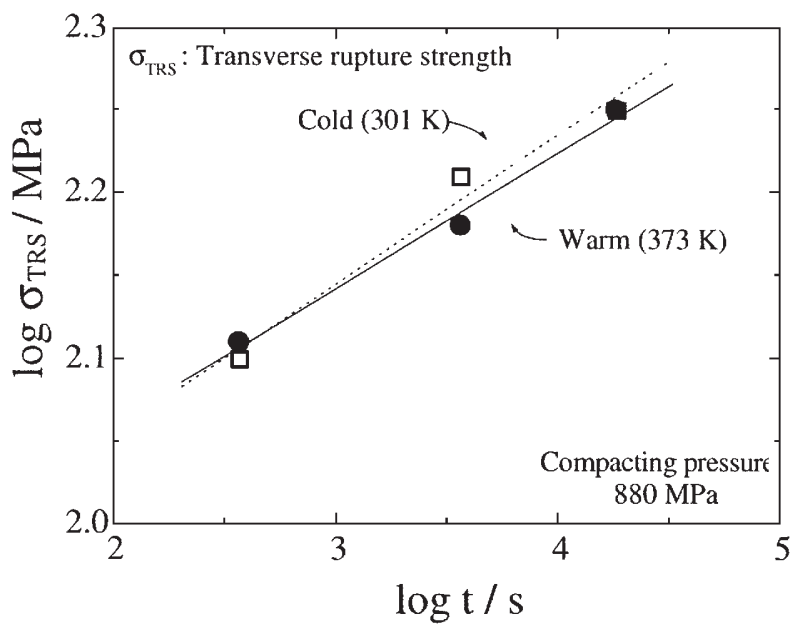

Fig.12 Double logarithmic plot of the transverse rupture strength versus the sintering time (Compacting pressure: $880 \mathrm{MPa}$ ).

$\mathrm{Mg}$ 粉末の降伏強度の温度依存性による塑性変形能の向上 と考えられる。

(5) 粉末粒子の塑性変形能の向上により, 粉末粒子同士の良 好な接触が得られ，新生面の生成が促進されたため抗折 力は增加したと考えられる. 以上のことから, 焼結の進行 が認められ, 純Mg粉末に対する温間成形法の有效性が示 された。

\section{文献}

1) T. Watanabe and Y. Horikoshi: "The Sintering Phenomenon of Titanium Powders-a Discussion", Int. J. Powder Metall. Powder Technol., 12(1976)209-214.

2) M. Ohtsuki and T. Kohno: "Effects of Addition of Sintering Aids on Sintering of Aluminum Containing Powders", J. Jpn. Soc. Powder Powder Metallurgy, 36(1989) 723-726.

3) J. Asami: "Compacting Characteristics on Two-step Pressing of Al powder", J. Jpn. Soc. Powder Powder Metallurgy, 41 (1994)131-135.

4) Y. Tatsuzaki, N. Momozawa, M. Abe, K. Takagi, and K. Nishiyama: "Mechanical Properties of P/M Mg-Boride Alloys", J. Jpn. Soc. Powder Powder Metallurgy, 45(1998)430-435.

5) R. Irmann: "Sintered Aluminum with High Strength at Elevated Temperatures", Metallurgia, 40(1952) 125.

6) K. Nishiyama, T. Nagata, K. Takagi, M. Omori, and S. Umekawa: "Mechanical Properties of Al Based Composites Reinforced with $\mathrm{AlB}_{12}$ and $\mathrm{MgB}_{2}$ ", J. Jpn. Soc. Powder Powder Metallurgy, 41(1994) 162-165.

7) H. Higuchi, M. Sugamata, and J. Kaneko: "Oxide Dispersed Materials Prepared by Reaction Milling of $\mathrm{Al}-\mathrm{Li}$ and $\mathrm{Al}-\mathrm{Li}-$ Mg Alloys with Various Oxides", J. Japan Inst. Metals, 60 (1996) 1207-1214.

8) K. Nishiyama: "Sintering and Tribology of Boride Hard 
Materials", J. Jpn. Soc. Powder Powder Metallurgy, 43(1996) 464-471.

9) Y. Takeda, K. Akechi, and T. Fujiwara: "Developments of Rapidly Solidified Aluminum Alloys", J. Jpn. Soc. Powder Powder Metallurgy, 43(1996)873-878.

10) Y. Yoshida, H. Yamada, S. Kamado, and Y. Kojima: "Microstructures and Tensile Properties of ECAE Processed Mg-Al-Zn Alloys", J. Japan Inst. Light Metals, 51(2001)556562.

11) M. Kamakura, H. Shibata, K. Nishiyama, and K. Tokaji: "Fabrication and Mechanical Properties of Mg-Zn Alloys by Powder Extrusion", J. Jpn. Soc. Powder Powder Metallurgy, 52(2005)404-410.

12) A. Aruga and H. Katsuta: "Pressureless Sintering of Vanadium Nitride Ceramics and their Properties", J. Jpn. Soc. Powder Powder Metallurgy, 48(2001)45-50.

13) H.G. Rutz and F.G. Hanejko: Int. J. powder metallurg, 5(1994)
117-133.

14) A. Simchi and G. Veltl: Powder Metall., 46(2003) 159-164.

15) K. Ueda, T. Machida, M. Iwakiri, and K. Fukagawa: Hitachi Powders Metals Technical Report, 1(2002)24-31.

16) T. Mizushima, H. Saikawa, and T. Minegishi: Collected Abstracts of the 1990 Spring Meeting of the Japan Inst. Light Metals, (1990)101-102.

17) H. Yamamoto: "Compacting and Sintering Properties of Ultrafine Tungsten Powders", J. Jpn. Soc. Powder Powder Metallurgy, 17(1971)198-205.

18) T. Watanabe: "Construction of General Equations on Powder Sintering and the Examinations", ZAIKEN, 51(1995)46-57.

19) Powder Metallurgy Technical Society: "Funmatsu Yakin Sosetsu Shoketsukiko", The Nikkan Kogyo Shimbun, LTD., (1964) 140.

20) S. Morozumi: Physical Metallurgy for Engineers, Agne Technology Centre, (1962) 241. 